\title{
ANALYSIS OF THE NEWS CONCERNING THE ROMA MINORITY IN BULGARIA*
}

\begin{abstract}
Bahar Ayaz $^{* *}$
ABSTRACT

In this study news discourses dealing with the Roma minority in Bulgaria are analyzed. One of the most problematic issues facing Bulgaria in terms of the EU membership process was its attitude toward minorities. The government implemented several policies in this regard and was finally accepted as a member. The overall situation of the Roma minority has improved over time, but has the perceptions of society and the attitude of the media also changed with regard to minorities? This study is seeking answers to these questions. Media discourse plays an important role concerning the determination and maintenance of dominant ideas. Therefore this study mainly focuses on the news discourse related to the Roma minority. As a result it is observed that the news discourse maintains the current prejudices and ideologies about the Roma minority. In news items, the Roma minority are represented as marginal or different people who reside in illegal settlements, people who are more tolerant of violence, and people who need to be protected.
\end{abstract}

Keywords: Bulgaria, discourse, news, EU, Roma minority.

\section{BULGARISTAN'DAKİ ROMAN AZINLIĞINA İLIŞKİN HABERLERIN ANALIZI}

ÖZET

Bu çalışmada Bulgaristan'daki Roman azınlığı ile ilgili haber söylemleri analiz edilmiştir. Bulgaristan'ın $A B$ üyelik sürecinde karşılaştığı en sorunlu konulardan birisi azınlıklara yönelik tutumu olmuştur. Bulgaristan hükümeti bu konuda çeşitli politikalar uygulamıştır ve sonunda $A B^{\prime} y e$ üye olarak kabul edilmiştir. Roman azınlığın ülkedeki genel durumu zamanla iyileşmiştir, ancak acaba toplumun algisı ve medyanın tutumu da azınlıklara yönelik olarak değişmiş midir? Bu çalışma bu sorulara cevap aramaktadır. Medya söylemi baskm fikirlerin belirlenmesi ve sürdürülmesinde önemli rol oynamaktadır. Dolayısıyla bu çalışma çoğunlukla Roman azınlı̆̆a ilişkin haber söylemine odaklanmaktadır. Sonuç olarak, haber söyleminin Roman azınlık hakkındaki mevcut önyargıları ve ideolojileri koruduğu gözlemlenmiştir. Haberlerde, Roman azınlığı yasadışı yerleşimlerde ikamet eden sıra dışı veya farklı insanlar, şiddete karşı daha hoşgörülü kişiler ve korunması gereken insanlar olarak temsil edilmiştir.

Anahtar Kelimeler: Bulgaristan, söylem, haber, AB, Roman azınlığı.

\footnotetext{
* This article is the extended version of the study which was presented in the Researchfora International Conference that held in Berlin between 03-04 March 2017.

** Arş. Gör., Gazi Üniversitesi İletişim Fakültesi Gazetecilik Bölümü
} 


\section{INTRODUCTION}

The Roma minority has lived throughout Europe for centuries, and Bulgaria is one of the countries in which a Roma minority live. Although these minorities seem to have been integrated into the various European countries, they face some distress in that most of the country's population do not face and face various unequal situations. This inequality shows itself in many different situations, but this study will focus on how the media reports the Roma minority. The language used by the media reinforces opinions that are prevalent in society. For this reason, news related to this minority will be examined. These news will be examined in terms of the Bulgarian media. The issue is limited to the Bulgarian media because the attitude of each country towards minorities will vary. In this study, the media of other countries were excluded because the desire was to examine in detail the news related to the Roma minority as published by the Bulgarian media.

Although Bulgaria became a European Union (EU) member in 2007, it was excluded from the 2004 enlargement because it would not have been able to meet the EU conditions. One of the main problems in this respect was the Roma minority. Although the largest minority group; Turks seem well integrated, this was not the case with the Roma minority. In 2003 Bulgaria adopted an Action Plan for the implementation of the Framework Program which included an antidiscrimination policy. In the same year, Parliament adopted the Protection Against Discrimination Act which guarantees equality of all individuals. However, there was no policy regarding the Roma minority's integration into Bulgarian society. Therefore the EU Commission declared "Since the last Regular Report, the situation of the Roma minority has barely improved" (Regular Report: 2003). The EU Commission shamed the Bulgarian authorities in the international and domestic media with coverage of the regular monitoring reports.

The EU reports and other necessary examinations meant that Bulgaria became a member state of the EU after convincing the EU that Bulgaria's progress in human rights had improved. But is this really the case? How is the Roma minority treated by the media? Even if there has been political progress, does it also mean that there has been progress in terms of media representation? And what language is used in the news? This study is basically seeking answers to these questions. In this study, the Bulgarian media's news about the Roma minority is analyzed through the use of critical discourse analysis. News items related to minorities are examined through www.novinite.com. In the scope of this study, the EU's human rights policies and its approach towards Bulgaria on the protection of minorities are also discussed, in order to form a basis for the later part of the study. 


\section{METHOD AND THEORETICAL FRAMEWORK}

Within the scope of this study, critical discourse analysis which's aim is "to shed light on the linguistic discursive dimension of social and cultural phenomena and processes of change in late modernity" (Jørgensen and Phillips 2002: 61), will be conducted in accordance with the critical theoretical literature. The analysis of critical discourse is an exploration of the analytical discourse on how social power, abuse, domination and inequalities are produced and actuated, and how this is countered by texts and dialogue in a social and political context. With this kind of research, critical discourse analysts establish a clear stance and ultimately resist such inequality (Van Dijk 2005: 352). The critical discourse analysis method will be used to investigate the discourse of the dominant ideology in society, and in particular in the media.

One of the thinkers who come to mind first when ideology is the subject is Althusser. According to Althusser (2014: 144) news, since it is part of the ideological apparatus of the state, is an important tool for the reproduction of the capitalist social formation. According to Gramsci (1971), media is one of the most important means of ensuring hegemony. Herman and Chomsky (2010: 2) also argue that media driven by a government plays an important role in the production of consent. Although even reporters themselves believe that they interpret the news objectively, actually the media set the agenda according to the interests of the government. In other words, media acts in a way to preserve privileges instead of trying to capture objectivity and reality by exhibiting a biased attitude. Another theorist who dealt with ideology is Foucault.

Foucault states that knowledge also exists in discourse within power relationships. The "normal people" discourse creates the existence of the unusual by society. According to Foucault (1980), subject is created by power, and society tries to legitimize the view of the normal by creating what is normal and what is not. In so doing, it strengthens the dominance of certain pre-assumptions. Discourse and power are also in contact with each other. Discourse is a tool for seizing power. The discourse of modernity is the dominant discourse by which we can understand the reality around us. As Foucault argues, subjects and social beings exist in discourse, therefore he prefers to use the concept of 'discourse' rather than 'ideology', because he says that the subject does not create an ideology. On the contrary, it exists in discourse. Views on this subject are varied. For example, by taking the concept of ideology in the context of media studies, Stuart Hall (2001) has moved research into media and ideology to a new dimension, recalling that every reader can make a difference from the text he reads. But this study mainly focuses on discourse, rather than on the other aspects of ideology, and therefore the preferred method is critical discourse analysis. 


\section{THE EU'S HUMAN RIGHTS POLICIES AND ITS APPROACH TOWARDS BULGARIA}

European societies can be considered as multicultural societies that have emerged as a result of techno-economic changes realized first in the industrial period, then in the post-industrial age. Technological changes, specifically global transportation and migration, gave way to the increasing diversification of social and cultural spheres on the one hand, and the coming together of different groups on the other. The increase in cultural diversity within the nation state is a consequence of these global movements. Moreover, the liberal democratic system in Europe makes cultural diversities more apparent in society. Therefore, the multicultural characteristic of European societies has been one of the main issues in dealing with human rights, especially minority rights.

However, the political development after the Industrial Revolution led to the formation of nation states that are more or less characterized by a homogenous people and a majority culture. In this sense, we can see that multiculturalism has become important in the modern era when nation states were becoming dominant. The concept of multiculturalism has become a very controversial subject, especially for the European states. Although it has become an important concept in terms of minority rights, some scholars criticize the concept for various reasons. On the one hand, multiculturalism refers to the coexistence of different religious, ethnic and/or linguistic groups within a society and nation state as the corresponding political unit. On the other hand, multiculturalism is seen as a response to the management of cultural diversity within the nationstate, so that minorities have equal rights and are equally involved in political decisions. The advocacy of the recognition of cultural characteristics by public institutions has been one of the most controversial debates in social sciences since the 1980s (Kastoryano 2009: 4). The debate on protecting minorities and their rights is still important in terms of social sciences.

However, multiculturalism functions not only as a response to diversity, but also as a tool with regard to limiting it. This understanding reveals a contradiction. Multicultural policies, while acknowledging the diversity of communities, presuppose that this diversity ends at the borders of the minority communities. They are trying to institutionalize diversity by placing people in ethnic and cultural boxes, for example into a homogenous Muslim community (Malik 2015: 21). According to Taylor (1997: 12) multiculturalism is related to the dominance of some cultures over others, and the imposition of this dominance. Western liberal societies are thought to be extremely guilty in this respect, partly due to the marginalization of population segments originating from their colonial past.

For the EU, as well as the case of multiculturalism, human rights have also been an important issue for a long time; in fact the multicultural society is at the center 
of the human rights debates. One of the critical milestones was the 1991 Declaration of the European Council on Human Rights. The 1991 Declaration elevated the priority given to human rights issues and served as the basis for EU initiatives in this area. The Declaration also introduced a set of specific goals of particular significance, including the protection of minorities, democracy, pluralism, and the protection of human dignity (European Political Cooperation Documentation Bulletin 1986: 57). The Treaty on EU's provision was also important. It denotes the objectives of "...developing and consolidating democracy and the rule of law, and... respecting human rights and fundamental freedoms" (Article 130, 2, EC Treaty). We see the importance given to human rights in all the written texts of the EU. The EU has also consistently emphasized the importance of political conditionality in its relations with the CEEC's. The Lisbon conclusions of June 1992 reaffirmed that '...any European State whose system of government is founded on democracy may apply for EU membership' (Conclusions of the Presidency, European Council: 1992). But the most obvious human rights standards in Europe, the Council of Europe's European Convention on the Protection of Human Rights and Fundamental Freedoms, is not uniformly adhered to by all Member States, some of whom have not ratified certain of its protocols (Rangelov 2001).

The EU accepted two new member states in January 2007, one of which was Bulgaria which had been excluded from the 2004 enlargement because it would not have been able to meet the conditionality criteria. The membership of Bulgaria was adopted in March 1998 and was consecutively reviewed in December 1999, January 2002 and May 2003. The Commission declared that it would repeat the recommendations of the Commission's Regulations on short and medium-term priorities identified as necessary to meet the membership criteria.

There are two basic approaches to the protection of minorities in international law practice - the application of anti-discrimination norms, and support for minority rights. After extensive discussions with Roma organizations and nongovernmental organizations, the Roma Equalization Framework of the Bulgarian Integration Program was adopted by the Bulgarian Government in April 1999. The program has drawn up a comprehensive plan with concrete measures in eight areas: legislation against discrimination, employment and economic development, health and sanitation, housing and neighborhood regulation, education, protection of Roma cultures, improvement of the presence of these minorities in the national media, removal of discrimination against Roma women (Noutcheva 2006: 156). After this program, the 2004 EU Progress Report stated that Bulgaria had fulfilled the political criteria and had deepened the stability of institutions that respect democracy, the rule of law and the protection of minorities in the previous year. The legislation against discrimination had been 
adopted, but the necessary independent body had not yet been established. Freedom of expression and respect for human rights are vital to efforts in the areas of child welfare, trade and anti-Roma prejudice (Lundström 2006: 21). Also the 2005 Comprehensive Monitoring Report maintains that Bulgaria continued to fulfill the political criteria and was judged to have reached "...a satisfactory level of compliance with EU requirements" (Lundström 2006: 24). But there were views which supported that the Commission's reporting procedure in assessing Bulgaria's progress in human rights did not reflect the reality in Bulgaria. Rather than collecting information or initiating independent research on the part of its own research and evaluation experts, it based its decision on official information from government or public administration resources. Perhaps for this reason, the reports sometimes lost their validity. However, on the other hand, the term "human rights conditionality" is so controversial that it does not offer any guidance or description. The Commission report "Minority rights and protection of minorities" has traditionally been Bulgaria's weakest aspect. However, similar conditions exist in some other EU Member States.

\section{ROMA MINORITY IN BULGARIA}

The history of the Roma people becoming minority is quite old, and they are thought to have migrated from northern India. It is believed that the Roma probably lived in Persia in the 7th Century and started migrating to Europe in the 10th Century (Fraser 1995). Later they lived in the borders of the Ottoman Empire for centuries (Marushiakova and Popov 2001: 20). Roma have lived in various countries of Europe since then, with one of these countries being Bulgaria. Bulgaria host minorities such as Turks and Roma. Roma are so much integrated into the country that all Roma activists in Bulgaria do not wish to see the word "integration" used in state policy, because Roma have lived in Bulgaria for centuries (Marushiakova and Popov 2004: 94).

The vast majority of Bulgaria is populated by Bulgarians. The second largest group is the Turks, and the third group is the Roma minority. Roma are not only living in Bulgaria, but they are living in most parts of Europe. Consequently, they face various problems. "When Roma did migrate to the West, they often found little welcome and were sometimes summarily deported to their countries of origin" (Rechel 2008: 183). Although the Roma minority are admired free spirits in Bizet's Carmen or George Barrow's Romany Rye, they are despised as criminals and historically oppressed people in reality, and they are the biggest losers following the demise of communism in Europe (Cooper 2001: 69). The Bulgarian view of the Roma is not much different from that of the rest of Europe.

The fact that the Roma minority do not live in their own country has caused them various troubles. In this sense, the Nazi persecution was the worst. Like Jews, the Roma were forced into labor (Crowe 1996). Although it is no longer so harsh, 
Roma people living in Bulgaria face various problems. They are more than three times likely to be unemployed than ethnic Bulgarians and the prospects of longer unemployment has been observed (Kolev 2002: 8, 35). The unemployment of Roma is probably related to education, as Roma are the least educated population group in the country. Statistics demonstrate that $12.7 \%$ of all Roma between 25 and 64 years of age are illiterate, while only $7.2 \%$ of Roma have secondary or higher education (Bogdanov and Angelov 2007: 20). "The high percentage of Roma who are unemployed and dependent on public assistance has renewed resentment against the Roma because, as Bulgarians struggle to rebuild their country, often working two or three jobs to provide for their families, the Roma are seen as lazy, dishonest and unwilling to work and contribute to the progress of Bulgarian society" (Gabel 2009: 68). This negative perception towards Roma is not the only problem.

Another problem with regard to the Roma is related with poverty and living conditions. They suffer the worse living conditions when compared with the rest of the population. Apart from this, Roma tend to live in separate neighborhoods and unfortunately this segregation is sometimes forced (Bogdanov and Angelov 2007: 26). Although the Roma minority face problems in Bulgaria, the government is taking concrete steps. In 2006, a National Program for Improving the Living Conditions of Roma in Bulgaria was approved and it continued until 2015. This program included advances in terms of Roma neighborhoods and the building of new settlement with suitable funding (Bogdanov and Angelov 2007: 28). Apart from the basic problems such as poverty and living conditions, there are many different treatments that the Roma minority has to deal with. For example, how the Roma minority is represented is in media also an important issue; because media is a tool that reinforces the continued dominance of ideas.

\section{MEDIA REPRESENTATIONS OF MINORITIES}

According to Hall et al., (2013: 217) the capitalist state take necessary measures to things that contain a threat to its existence and the mass media maintains the existence of the capitalist state by consent production. Moreover, news items regarding minorities are framed by elite discourse. Media play an important and an active role in the reproduction of ethnic prejudices (Van Dijk 1987: 360). Media rather normalizes or marginalizes people by its coverage and frames. Therefore the under-representation of media is an important issue (Cottle 2000: 16) and news coverage of minorities constitutes a significant part of it. Thus, many scholars have examined the selection biases which are related with gender and race in news coverage of various types of victimization (Dixon and Linz 2000; Entman 2006; Lundman 2003; Meyers 1997). Similarly, Campbell (2013: 4) argued that news coverage ignore and marginalize non-white people. There are many different examples of this type of work. For example, relying on a content 
analysis of newspaper coverage of 100 representatives in the 2006 US midterm election, Gershon (2012: 106- 119) examined the role of race, ethnicity, and gender in campaign media coverage of US House members, and found that media's treatment of women and minorities are negative and limited.

Analyses of media discourses have shown that white elite groups are defining ethnic situations rather than minorities and governments provide most of the news sources in issues regarding immigration, socioeconomic policies, and social. Moreover negative frameworks such as terrorism and riots are used and prejudices that imply immigrants are illegal constitute most of the news stories. A perception that immigrants will burden the socio-economic resources is preferred to the perception that immigrants are a gain for the economy. For example the Germany's immigrant workers contribution to economy is not mentioned on news articles (Van Dijk 1987: 363-365). Moreover, when minorities are represented in the press, generally they are represented by the majority such as white politicians or lawyers (Van Dijk 2015: 154). Marginalizing the nondominant religious groups is also seen in media portrayals. Saeed's (2007: 443) study which examined the representation of Islam and Muslims in the British press, displays this marginalization. Saeed suggested that British Muslims are portrayed as an 'alien other' within the media.

Not only women, blacks or Muslims living in America, but people who don't hold the power living all over the world are subordinated by the media. Besides, there are several ways to create this subordination and reproduce the current ideology in news items. According to Fowler (2013: 84) the vocabulary choice is the basis of discriminatory practice when dealing with women and ethnic minorities. Additionally, for Entman (2006: 210), another way of reproducing the existing ideology is highlighting the dramatic quotes which fit audience stereotypes. When journalists report about the black political activity, they often choose quotes that convey drama and conflict. Although those quotes are not the only things the blacks say, they convey drama and induce emotion. Thus, black people are represented in a dramatic framework.

Like many other minorities, the Rome minority are also being alienated by the media. Therefore, many researchers have examined the representation of Roma minority by giving importance to the power of media. There are several articles on the representation of Roma minority in the media. For example; Csepeli and Simon (2004) discussed the construction of Roma identity in Eastern and Central Europe, Sigona (2006) examined the political participation and media representation of Roma in Italy, Munk (2007) analyzed Roma stars' image change in Hungarian media, Varjú and Plaut (2017) covered the Roma migration to Canada in Hungarian and Canadian press, Schneeweis (2017) analyzed the American news coverage of the Roma, Schneewei and Foss (2016) examined the 
representations of Roma culture in American Television and Pivettiet al. (2017) explored the social representations of the Roma woman in Italy and Brazil. Apart from these studies, there are articles which especially deal with media discourses concerning Roma minority. For example, Vidra and Fox analyzed (2014) the antiRoma discourses in the Hungarian media, Erjavec (2001) analyzed the media representation of the discrimination against the Roma in Slovenia. Apart from the studies that analyze the media discourses of Hungaria and Slovenia media, there are also articles that examine UK news items discourse. For instance, YuvalDavis et al. (2017) examined press discourses on Roma in the UK, Finland and Hungary. Richardson (2014: 59) also analyzed the UK newspapers discourse concerning Roma minority and found that Roma are 'ghettoized' and they are reimagined and re-constructed as 'other'. This study differs from previous studies in that it deals with the discourse of a Bulgarian news agency's news items about the Roma minority. The representation of the Roma minority in Bulgarian media, which constitutes a sizable amount of Bulgaria's population, is a matter to be considered. However, this study aims to provide a more in-depth analysis by examining fewer news items, rather than revealing a quantitative analysis of numerous news articles.

\section{ANALYSIS OF THE NEWS CONCERNING THE ROMA MINORITY}

In this study, news related to the Roma minority is examined through www.novinite.com using the critical discourse analysis method. Novinite is a Bulgarian news agency which presents news in English. Novinitegroup.com is a media group that has many different sites and dominates Bulgaria's online media market. To achieve an understanding of the minority news, critical discourse analysis was the preferred method. This is because it is assumed that there are some meanings that cannot be seen on the surface, and consequently it aims to identify hidden meanings. Thirty news items published in 2016 and 2017 were examined as part of this study. Within the scope of the study, macro and micro structures of the news are examined. News headings, word choices, news, news sources and photographs are taken into consideration.

\section{News, headings, overall themes and photograph}

In this section, headings, subheadings, spots, the news itself and photographs are examined. When headlines are examined, it appears that an objective attitude is adopted. No insulting headings with regard to the Roma minority were found in the titles. Typically, the titles include "Refugees, Romans Continue to be Mistreated in Bulgaria" and "Nationalism and Unchecked Violence in Bulgaria".

In general, it can be said that there are two different attitudes identifiable in the news. The first is news that highlights negative attitudes toward minorities. In such items, discriminatory attitudes towards the minority group are criticized. 
The second attitude emerges in the news that reinforces the thoughts that alienate minorities. In these news items, the Roma people are reflected as the others, or people who are different from Bulgarians. However, even in those news items that criticize the attitude towards the Roma minority, a discriminatory discourse towards these minorities is being used.

For example, one of the news items claimed that members of the Roma minority in Bulgaria are being deprived of their rights. It is argued that that the Roma community and the Roma minority in Bulgaria are deprived of their right to learn their mother tongue as they are being denied legal definition as a minority. But this news also presents the opposite view which claims that accusations that the constitution of the country puts an obstacle in the way of the existence of ethnic minorities "do not match reality". One other news item argued that the Roma minority, who number 400,000 in Bulgaria according to official statistics, are the largest and most frequently attacked ethnic group. Another news item states that Bulgaria has continued to evict Roma communities from illegal and informal settlements, with some minorities relocated to inadequate housing, whereas others were left homeless. Another news item argued that the marginalization of the Roma minority remains Bulgaria's most pressing human rights problem. In such news items, the attitude of the Bulgarian administration towards the Roma minority is criticized in general. In fact, this is the attitude that emerges in the news in general. However, a different situation arises when the discourses of the news are examined.

It is stated in one news item that a protest action was staged a day after a large scale fight occurred between Roma and local people. The reason for this was the loud music coming from the Roma neighborhood. Soon after the violence broke out, some people used axes and other sharp objects in the fights. Reportedly, four Bulgarians were injured and eight Roma people were held in custody. As several protesters stated, the reason for the demand was not the earlier violence. A number of people stated their belief that their homes had been robbed by representatives of the ethnic minority. In this news item, the Roma minority have been shown as people who disturb the local community through excessive noise. In addition, without any specific source in the news, the use of an indefinite expression such as "some people" has been used, and it is stated that "some people say that the Roma minority have robbed villas". In this news item, the Roma minority are presented as people who cause conflict without providing any evidence. Besides, the majority of the news item argued that Roma housing in the neighborhood had been built illegally, and local authorities said that the houses would be destroyed. Such news often represents the Roma minority as people who are aggressive and engage in illegal settlement. For example, a news item about tensions between ethnic Bulgarians and Roma residents only focuses on the damage that the Roma residents caused, and ignore the damage caused by 
Bulgarians. News items state that ethnic Bulgarians were beaten and left with serious injuries by four Roma people. Another news item which is about a barbaric attack on a woman in the Berlin metro by Bulgarian nationals advertently highlights that the attacker lives in the Roma ghetto of Maksuda and has a substantial criminal record of hooliganism, robbery and other offenses.

Table 1. Analysis of News Items of Novinite.Com Concerning the Roma Minority

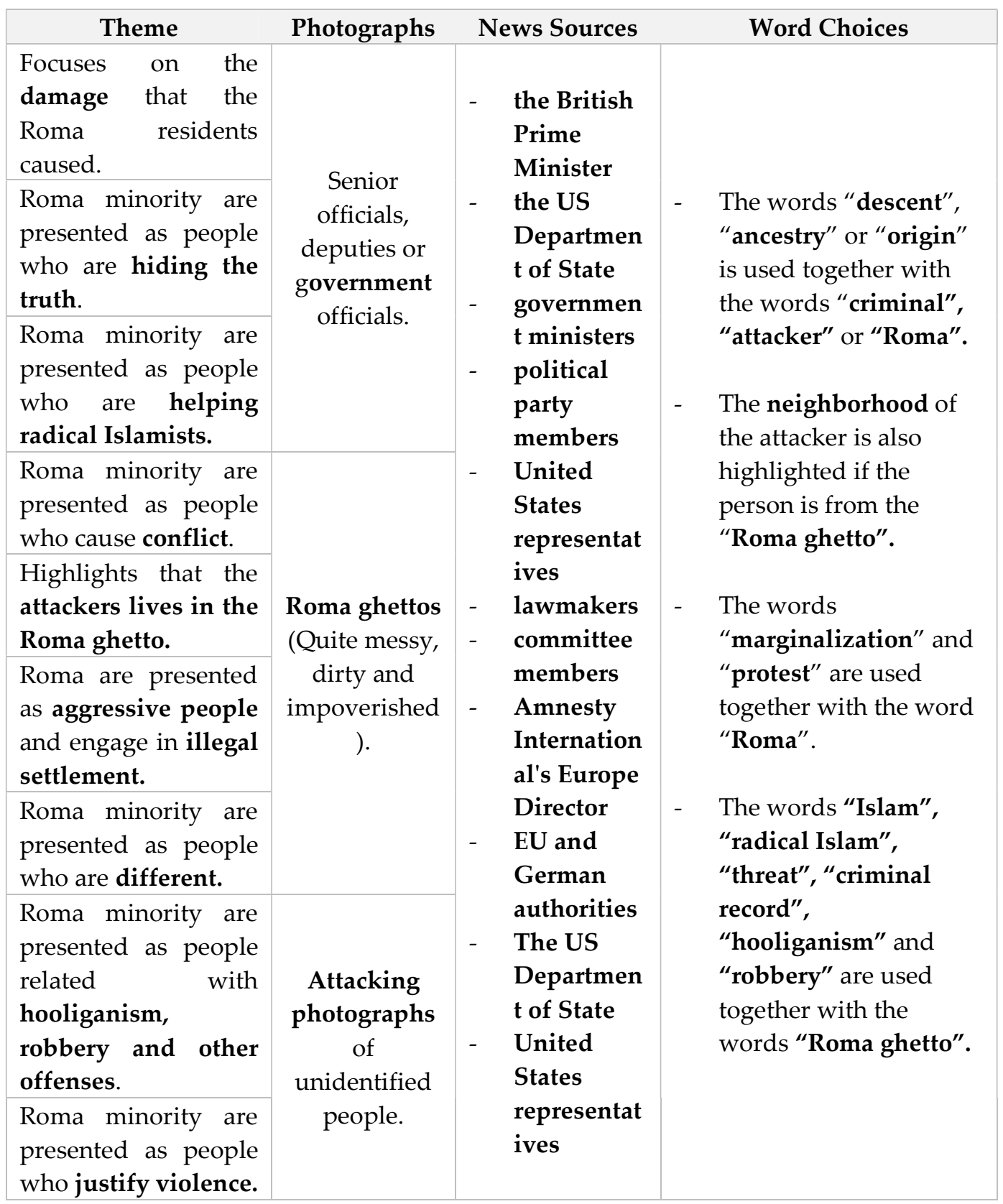


Many news items highlight the differences of the Roma minority. For example, a news item claims that hundreds of people from Bulgaria and Romania currently travel to Sweden to beg on the streets, and highlights that those people who came from Bulgaria are from the Roma communities. A news item which is related to violence and rape is also an example of this marginalization. This news item stated that $60 \%$ of Romanians justify violence, whereas only $22 \%$ of British accept such a crime. $52 \%$ of Bulgarians think that constant criticism of one's partner in order to make them feel inferior is unacceptable, whereas $40 \%$ believe that inappropriate sexual comments or "jokes" directed towards women are acceptable. In this news item, there is an emphasis that Roma people justify violence, when compared to the Bulgarians and the British. The Roma minority are reflected as people who are more tolerant of violence.

One of the news items stated that Bulgaria's Pazardzhik City banned the wearing of full-face veils in public places. It is argued that all political parties backed the proposal with the exception of the Euroroma party, which is committed to defending the interests of the Roma population. In this news item it was said that burqas had never been typical for Bulgarian Muslims and their wearing them was an attempt to split Bulgarian society. The burqa has been rejected by Bulgarian society as a whole, but has not been rejected by the Euroroma party, which is also supporting the Roma minority. The news item stated that the wearing of the burqa is aimed to divide society, and therefore the Roma minority is shown as a group that wants to divide society. This news item is not the only one that implies that there is a link between Islam and the Roma minority.

A news item entitled "Radical Islam Witnesses in Bulgaria's Pazardzhik Withdraw Statements" stated that the witnesses from the Roma neighborhood stated that, when preaching, Ahmed Musa discussed religion only, and how to pray correctly. In court, Ahmed Musa asked some of the witnesses whether he had ever said that Islam must be imposed on the territory of Bulgaria by means of warfare. The answers were "No". The news item claimed that the witnesses from the Roma neighborhood were indeed wrong by saying "...after an intervention on the part of the prosecution, however, it became clear that the book Apostasy was distributed in the Abu Bekir mosque in Pazardzhik. The book is banned in European countries on the grounds that it calls for jihad". The news item raised doubts about the Roma people as if they are people who are hiding the truth and helping radical Islamists.

When the photographs used as part of news items are examined, it can be seen that the photographs generally include news actors. These news actors are usually not people from the Roma minority. Rather, they are senior officials, deputies, various responsible people from the government. These people are represented in an upright position and in a confident manner. But some news 
items about the Roma minority feature images of Roma ghettos. These images are generally of slums. For example, the photograph of a Roma ghetto is used in a news item that emphasizes the marginalization of the Roma people. In one photograph there is a structure that does not resemble a house at all. There is something like a tarp instead of walls, and clothes are hanging everywhere. Moreover, this structure is quite messy, dirty and impoverished. Therefore, in fact, this photograph itself alienates the Roma minority. Despite the fact that there are many regions and many decent houses inhabited by the Roma minority, the choice of this photograph is maintains the current discourse within society.

\section{News sources}

The choice of news sources is important; this is because the selection of news sources demonstrates the perspective of the news organization. In other words, news sources determine the choice of the views that are to be transmitted to the audience. In the news about minorities, there is a considerable difference between giving the opinions of a state representative on the subject and giving the opinions of ordinary people. When the Novinite news agency's news about Roma minorities is examined, it can be seen that government officials are generally used as news sources. Prominent sources of the news concerning the Roma minority are mainly state officials such as the British Prime Minister, the US Department of State, government Ministers, political party members, United States representatives, lawmakers, committee members, Amnesty International's Europe Director, EU and German authorities.

The choice of Krasimir Karakachanov who heads the VMRO party as a news source also supports this idea. Karakachanov states: "I am really curious what kind of people they are. If they are Romanian citizens, they should be taken back by Romania. They also have a king there. He is the Romanian Gypsy King, but looks after them." The choice of this quotation helps to maintain the current view towards minorities.

Another news source was the British Prime Minister, Theresa May. She said "Half of Romania and Bulgaria might move to the UK before Brexit". Her statement reinforces the belief that minorities are a threat to society. It would not have been a problem that a great number of minorities might migrate to the UK if the minorities were not perceived as a threat to British society. Apart from this, the sentence; "half of Romania and Bulgaria" is definitely an exaggeration, as it is something that could not possibly become reality.

\section{Word choices and sentence structures}

In this section, word choices and sentence structures are examined. Figure 1 demonstrates most used words in the news items. The numerous uses of the 
words such as "Bulgaria", "Bulgarian", "government" and "country" show that even news items which are related with Roma minority make mention of the majority more than the Roma minority. Moreover, in some of the sentences that mentioned the Roma minority, the words 'marginalizing', 'marginal' and 'marginalized' have been used. Moreover when a criminal is mentioned in the news, and if that criminal belongs to the Roma minority, the belonging of this person is definitely emphasized and the words "descent", "ancestry" or "origin" is used together with the words "criminal", "attacker" or "Roma". Sometimes the neighborhood of the attacker is also highlighted if the person is from the "Roma ghetto". News item which covers an attack that highlights where the attacker lives, is an example of this situation. The news item tells, in the same sentence, that the attacker has a substantial criminal record of hooliganism, robbery and other offenses and that the attacker is living in the Black Sea City of Varna's Roma ghetto. The word 'violence' is also used in the same sentence with 'Roma minority' in more than one news item. When the sentences are examined, it can be understood that the words "marginalization" and "protest" are used together with the word "Roma". The words "Islam", "radical Islam", "threat", "criminal record", "hooliganism" and "robbery" are used together with the words "Roma ghetto" in the same sentence.

It can also be seen that the tags of the news items sometimes consist of the words 'violence' and 'Roma minority' together. According to Turow and Tsui (2008: 71) the news tags which are among the hyperlinks, "...allows news providers to suggest which voices are worthy of our attention and which voices are not." Therefore, the technology that supports hyperlinks is not much different than the old forms of media in terms of decision-making. In addition, as pointed out earlier, media is a tool for the reproduction of the capitalist system. Based on this, it can be said that the news tags of the site Novinite are also promoting the current view of society and discourse towards the Roma minority.

As pointed out in the previous section, in some of the news items the Roma minority have been associated with Islam in the same sentence. The Roma people have even been associated with radical Islam. Muslims who differ from the rest of society for religious reasons and the Roma minority which are different in terms of their ethnic belonging, are handled in the same frame. Muslims are perceived as a threat to the prevailing values in society. This perception is also reflected in the news. The Roma minority were also reflected as being different, therefore attempts were made to make it look as if these people were cooperating with Muslims. The use of such news items is causing a particular perception: the Roma minority has entered into co-operation with radical Islamists; therefore they are posing a threat to society. For example, a news item stated that a group of Islamic State supporters was arrested in the fall of 2014 in the Roma ghettos. With this news, the Roma minority is also associated with terror. This is because 
the Islamic State (IS) / ISIS is a terrorist group which has executed many people all over the world.

Figure 1. Most Used Words of the Analyzed News Items

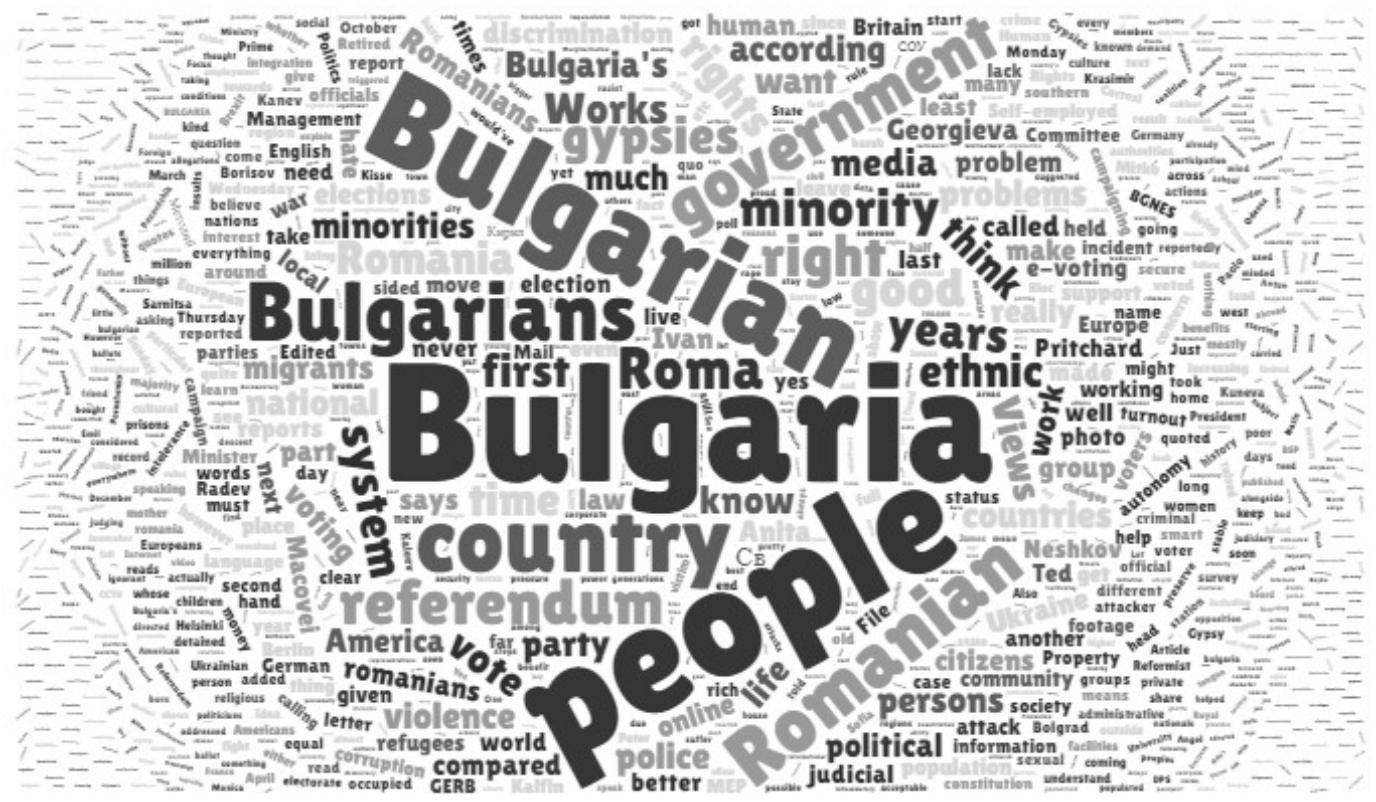

When we look at the words used in the news, we see that sometimes the word "gypsy" is used to express the Roma minority. Gypsy is an expression that is not liked by the Roma minority. Although the word is used in the literature to identify these people, some people consider this word pejorative because of its connotations with illegality and irregularity.

When we look at news with regard to the Roma minority, the following result is also observed: People from the Roma minority are reflected in the news as a single, homogeneous group. The reason for such a reflection lies in an ideology that emphasizes the difference of the Roma minority from the West. It is often emphasized that they are from the Roma minority when violence occurs.

\section{CONCLUSION}

Bulgaria became an EU member in 2007, after the EU was convinced that Bulgaria's progress in terms of human rights had improved. There was political progress, but does it also mean that there has been progress in terms of media representation? This study has tried to find an answer to this question and has examined the discourse in the news about the Roma minority. In conclusion, it seems that there is no obvious discourse in terms of hate speech or humiliating expressions used against minorities. Nonetheless, the Roma minority is 
represented as aggressive and different people who reside in illegal settlements. Even in the news items that highlight that the rights of minorities need to be protected, or that the Roma minority is exposed to inequalities, there are discourses of alienation. Therefore, these minorities are not treated equally by the media today. The news coverage of minorities marginalizes these minorities, and the discourse maintains the existing prejudices and ideologies about minorities.

As a result of the analysis carried out, it is understood that there are two different attitudes in the news concerning the Roma minority -news that highlights negative attitudes toward minorities and news that reinforces the thoughts that alienate minorities. In general, the Roma people are reflected as others, or people who are different from Bulgarians. The Roma minority are reflected as people who are more tolerant of violence, who are aggressive and who live in illegal settlements. Apart from this, the news portrays the Roma as people who support radical Islam. The news raises doubts about the Roma people as if they are people who are helping radical Islamists. With the publication of such news the Roma minority is shown as a group that wants to divide society. The Roma minority is not only associated with Islam but are also emphasized as people who are different from other people in the West. Moreover they are represented as a single, homogeneous group.

The word choices, sentences and photograph choices of the news also support this idea. The use of words such as "marginalization" and "protest", together with the word "Roma" and the use of the words "Islam", "radical Islam", "threat", "criminal record", "hooliganism" and "robbery" together with the words "Roma ghetto" in the same sentence, maintains the marginal Roma image as it is portrayed to Bulgarian society. The use of photographs which shows; Roman ghettos as being messy, dirty and impoverished also alienates the Roma minority. Despite the fact that there are many regions and many decent houses inhabited by the Roma minority, the choice of this kind of image maintains the current discourse of society. Therefore, it can be said that the media reinforces the existing prejudices about the Roma minority and strengthens the dominance of certain preconceived assumptions.

\section{REFERENCES}

Althusser L (2014) On the reproduction of capitalism: Ideology and ideological State Apparatuses, Verso Books, London.

Bogdanov L and Angelov G (2007) Roma Integration in Bulgaria: Necessary Reforms and Economic Effects, Open Society Institute, Sofia.

Campbell C P, Le Duff K M, Jenkins C D \& Brown R A (2013) Race and News: Critical Perspectives, Routledge.

Conclusions of the Presidency, European Council, Lisbon, June (1992). 
Cooper B (2001) "We Have No Martin Luther King": Eastern Europe's Roma Minority. World Policy Journal, 18(4), 69-78.

Cottle S (2000) Ethnic Minorities \& The Media: Changing Cultural Boundaries, McGraw-Hill Education (UK).

Crowe D (1996) A History of the Gypsies of Eastern Europe and Russia, New York, St Martin's Press.

Csepeli G and Simon D (2004) Construction of Roma Identity in Eastern and Central Europe: Perception and Self-identification, Journal of Ethnic and Migration Studies, 30(1), 129-150.

Dixon T L and Linz D (2000) Race and the Misrepresentation of Victimization on Local Television News, Communication Research, 27, 547-573.

EC Treaty, Article $130-2$.

Entman R M (2006) Blacks in the News: Television, Modern Racism, and Cultural Change, Communication and Law: Multidisciplinary Approaches to Research, 205-228.

Erjavec K (2001) Media Representation of the Discrimination Against the Roma in Eastern Europe: The case of Slovenia, Discourse \& Society, 12(6), 699-727.

European Political Cooperation Documentation Bulletin (1986): 57.

Foucault M (1980) Power/Knowledge, Selected Interviews and Other Writings 1972-1977, Ed. by Colin Gordon, Tr. by Colin Gordon et al., New York, Pantheon Books.

Fowler R (2013) Language in the News: Discourse and Ideology in the Press.Routledge.

Fraser A (1995) The gypsies, UK and US, Blackwell Publishing.

Gatenio Gabel S (2009) The Growing Divide: The Marginalisation of Young Roma Children in Bulgaria, International Journal of Social Welfare, 18(1), 65-75.

Gershon S (2012) When Race, Gender, and the Media Intersect: Campaign News Coverage of Minority Congresswomen, Journal of Women, Politics \& Policy, 33(2), 105-125.

Gramsci A (1971) The Philosophy of Praxis, Selections From the Prison Notebooks of Antonio Gramsci, Elecbook, London.

Hall S (2001) Encoding/Decoding, Media and Cultural Studies: Keyworks, 166176.

Hall S, Critcher C, Jefferson T, Clarke J and Roberts B (2013) Policing the Crisis: Mugging, the State and Law and Order, Palgrave Macmillan. 
Herman Edward S and Chomsky N (2010) Manufacturing Consent: The Political Economy of the Mass Media, Random House, New York.

Jørgensen M W and Phillips L J (2002) Discourse Analysis as Theory and Method, Sage.

Kastoryano R (2009) An Identity for Europe: The Relevance of Multiculturalism in EU Construction, Springer, Springer, Berlin.

Kolev A (2002) Joblessness and Precarious Work in Bulgaria: Addressing the Multiple Aspects of Vulnerability in the Labor Market, Background Paper for the Bulgaria Poverty Assessment, The World Bank, Washington, DC.

Lundman R J (2003) The Newsworthiness and Selection Bias in News about Murder: Comparative and Relative Effects of Novelty and Race and Gender Typifications on Newspaper Coverage of Homicide, Sociological Forum, 18(3), 357-386.

Lundström L (2006) Europeanization Through Conditionality? Bulgaria and Romania in the EU Accession Process. Lund University, Department of Political Science.

Malik K (2015) The Failure of Multiculturalism: Community Versus Society in Europe, Foreign Aff., 94, 21.

Martin P B, Scullion L C and Brown P (2017) 'We Don't Rely on Benefits': Challenging Mainstream Narratives Towards Roma Migrants in the UK Philip Martin, Lisa Scullion and Philip Brown.

Marushiakova E and Popov V (2001) Gypsies in the Ottoman Empire: A Contribution to the History of the Balkans (Vol. 22), Univ. of Hertfordshire Press Hatfield.

Marushiakova E and Popov V (2004) The Roma-A nation without a state? Historical background and Contemporary Tendencies, Streck, Bernhard (Hg.): Segmentation und Komplementarität, Mitteilungen des SFB, Differenz und Integration, 6, 71-100.

Meyers M (1997) News Coverage of Violence Against Women: Engendering Blame, Thousand Oaks, CA: Sage.

Munk V (2007) "Play to me Gypsy!” How Roma Stars' Image Change in Hungarian Media', History of Stardom Reconsidered, Turku: International Institute for Popular Culture.

Noutcheva G (2006) EU Conditionality and Balkan Compliance: Does Sovereignty Matter? (Doctoral dissertation, University of Pittsburgh).

Pivetti M, Melotti G and Bonomo M (2017) An Exploration of Social Representations of the Roma Woman in Italy and Brazil: Psychosocial Anchoring to Emotional Reactions, International Journal of Intercultural Relations, 58, 12-22. 
Rangelov I (2001) Bulgaria's Struggle to Make Sense of EU Human Rights Criteria, EU Monitoring Accession Program, 1.

Rechel B (2008) What Has Limited the EU's Impact on Minority Rights in Accession Countries?, East European Politics and Societies, 22(1), 171-191.

Regular Report on Bulgaria's Progress Towards Accession, http://eurlex.europa.eu/legal-content/EN/TXT/?uri=CELEX:52003SC1210 Accessed on: 07.05.2017 23.40 (2003)

Richardson J (2014) Roma in the News: An Examination of Media and Political Discourse and What Needs to Change, People, Place \& Policy Online, 8(1).

Saeed A (2007) Media, Racism and Islamophobia: The Representation of Islam and Muslims in the Media, Sociology Compass, 1(2), 443-462.

Schneeweis A (2017) The Imagined Backward and Downtrodden Other: Contemporary American News Coverage of the Roma/Gypsy, Journalism Studies, 1-20.

Schneeweis A and Foss K A (2016) “Gypsies, Tramps \& Thieves” Examining Representations of Roma Culture in 70 Years of American Television, Journalism \& Mass Communication Quarterly, 1077699016682723.

Sigona N (2006) Political Participation and Media Representation of Roma and Sinti in Italy, OsservAzione/OSCE.

Taylor C (1997)The Politics of Recognition, New Contexts of Canadian Criticism, 98.

Turow J and Tsui L (2008) The Hyperlinked Society: Questioning Connections in the Digital Age, University of Michigan Press, Ann Arbor.

Van Dijk T A (1987) Communicating Racism: Ethnic Prejudice in Thought and Talk, Sage Publications, Inc.

Van Dijk T A (2005) Critical Discourse Analysis, in The Handbook of Discourse Analysis (eds D. Schiffrin, D. Tannen and H. E. Hamilton), Malden, Massachusetts, USA, Blackwell Publishers Ltd.

Van Dijk T A (2015) Racism and the Press (Vol. 5). Routledge.

Varjú V and Plaut S (2017) Media mirrors? Framing Hungarian Romani Migration to Canada in Hungarian and Canadian Press, Ethnic and Racial Studies, 40(7), 1096-1113.

Vidra Z and Fox J (2014) Mainstreaming of Racist Anti-Roma Discourses in the Media in Hungary, Journal of Immigrant \& Refugee Studies, 12(4), 437-455.

Yuval-Davis N, Varjú V, Tervonen M, Hakim J and Fathi M (2017) Press Discourses on Roma in the UK, Finland and Hungary, Ethnic and Racial Studies, 40(7), 1151-1169. 